\title{
Report vannevar bush: science the endless frontiers
}

\begin{abstract}
The present study is the result of the investigation centred on "Strategy and Knowledge in the Equation of NATO" and was based on "Report Vannevar Bush: Science the endless frontiers", which marks a unique moment in the scientific and technological policy-military and civil-of the United States of American and would influence a large number of nations of the world and of NATO where its principles were adopted.We followed a methodology of historical-scientific analysis because we thought that this would be the best way to present an overview of the "Report Vannevar Bush: Science the endless frontiers" that includes the following points of analysis: "Introduction"; "The War Against Disease"; "Science and the Public Welfare"; "Renewal of Our Scientific Talent"; "A Problem of Scientific Reconversion"; "The Means to the End".
\end{abstract}

Keywords: science, technology, scientific personalities, visions of scientific policy, scientific associations
Volume 3 Issue 3 - 2018

\author{
Jose Luis Assis \\ University of Évora, Portugal
}

Correspondence: Jose Luis Assis, Professor, Centro de Estudos de História e Filosofia da Ciência, University of Évora, Portugal, Tel 35 I-266-740-800, Fax 35 I217908300, Email joselassis@gmail.com

Received: February 05, 2018 | Published: June 07, 2018

\section{Introduction}

The report "Report Vannevar Bush: Science the Endless Frontiers" is part of a larger work "Strategy and Knowledge in the Equation of (NATO)" presented at the National Defence Institute to obtain the diploma of National Defence Auditor. The Report was requested on November 17, 1944 by President Franklin Delano Roosevelt (18821945) to engineer Vannevar Bush and delivered in July 1945 to President Henry S. Truman (1884-1972). It influenced the scientific and technological development of the United States and most of the nations of the world where its principles have been adopted. It also led to the creation of the "Science for Peace and Security" (SPS) on which the Non-Military Cooperation Committee was based for the preparation of the "Report of the Committee of the Three on nonmilitary cooperation in NATO". Several questions have guided our investigation of the "Endless Frontier":

a. What were the concerns that led to its emergence?

b. What importance was assigned by the US administration to Science and Technology in the modernization of the United States-economy and armed forces?

c. What research methods have been favoured and what kind of relationship has been established between the military and scientific institutions?

In this way, we propose to analyse the characteristics of the Report, highlighting issues related with strategic objectives, science and governance, science and national security, the mobilization of science for war and the fundamentals of military research.

The endless frontiers: contribution to a scientific and technological organization, an idea for the organization of science and technology

In 1942, US Senator Harvey Martin Kilgore (1893-1956) introduced a bill to create a government-supervised body to control research during World War II. ${ }^{1}$ This project was rejected, and then had a new initiative to organize a foundation to assist in post-war

'Zachary G. Endeless frontier: Vannevar Bush, engineer of the American century. New York: The Free Press, 1997. p. 219. research. ${ }^{2}$ Engineer Vannevar Bush (1890-1974) $)^{3}$ supported this idea, that the government should create working conditions for a scientific and academic community-universities and institutes-and respond to business objectives after the war. ${ }^{4}$ Vannevar Bush, a key figure in the development of the United States military-industrial complex, was appointed director of the National Advisory Committee for Aeronautics (NACA) in the late 1930s, and in 1941 by President Franklin Delano Roosevelt (1882-1945) 5 was nominated director of the Office of Scientific Research and Development (OSRD). As the director of this body, he supervised and was in close contact with the major scientific projects - the progress of radar and the atomic bomb ${ }^{6}$ - that from a strategic point of view would change the course of the conflict.

In November 1944, the scientists of the Manhattan Project ${ }^{7}$ ${ }^{2}$ Ibid.

${ }^{3}$ For a deeper study on this scientific personality consult: Wiesner J. 1979. Vannevar Bush (1890-1974). Washington DC, National Academy of Sciences, pp. 89-117. Owen L. 2001. Bush Vannevar (1870-1974). The history of Science in the United States, an Encyclopedia. New York: Garland Publishing Inc. p. 99-100.

${ }^{4}$ Zachary G. Endeless frontier: Vannevar Bush, engineer of the American century. NewYork: The Free Press; 1997. p. 219.

${ }^{5}$ Politician and statesman who served as senator, secretary of the navy and 32nd president of the United States (1933-1945). He implemented the war strategy on two fronts that it took to the defeat of the Axis power and created the Scientific Program that allowed the first Atomic Bomb to be developed. $\mathrm{He}$ is considered by scholars to be one of the three greatest presidents of the United States with George Washington (1732-1799) and Abraham Lincoln (1809-1865).

${ }^{6}$ Julius Robert Oppenheimer (1904-1967) was an American physicist responsible for the Manhattan Project for the development of the atomic bomb during World War II at the Los Alamos National Laboratory in New Mexico.

${ }^{7}$ The Project was born in 1939 and employed the leading scientists and thinkers and was executed under absolute secrecy. Kelly, C. 2007. Manhattan Project: The Birth of the Atomic Bomb in the Words of Its Creators, Eyewitnesses, and Historians. New York, Black Dog \& Leventhal Published. See still Rhodes, R., 2012. The Making of the Atomic Bomb: 25th Anniversary Edition. New York., Copyrighted Material. Groves, L., 1983. Now It Can Be Told: The Story Of The 
anticipated that in mid-1945 they would have the nuclear artefact ready and English and American scientists would have perfected radar for defense of the English cities from the German bombers and a greater diversity of technologies for the war effort. At this time President Roosevelt addressed a letter to engineer Vannevar Bush, who oversaw research for the defense of the United States, in which he posed four questions:

1. "What can be done, consistent with military security, and with the prior approval of the military authorities, to make known to the world as soon as possible the contribution which have been made during our war effort to scientific knowledge? The spread of this knowledge would help to stimulate new businesses, provide jobs for returning soldiers and other workers, and make it possible to improve national well being"; 8

2. "With particular reference to the war of science against disease, what can be now to organize a programme for continuing in the future the work which has been done in Medicine and related sciences? The fact that death from illness is much higher than the total number of lives lost during the war should make us aware of our duties towards future generations";

3. "What can the Government do now and in the future to aid research activities by public and private organizations? The role of public and private organizations as well as their interrelationship should be considered", ${ }^{10}$

4. "Can an effective program be developed for discovering and developing scientific talent in American youth so that the continuing future of scientific research in this country may be assured on a level comparable to what has been done during the war?". ${ }^{11}$

In the words of Zachary ${ }^{12}$ this task was facilitated by the fact that Engineer Vannevar himself wrote the letter in which he warned the president about the need to organize a modern science and technology system ( $\mathrm{S} \& \mathrm{~T}$ ) which would be improved and better structured than that which existed before the war. According to Kevles ${ }^{13}$ the letter with questions about the future of the research system was the subject of political discussion in the US Congress, as well as the Report itself. In fact, the research system in the United States and most countries of the world was poorly structured before the start of World War II. ${ }^{14}$ Few countries were endowed with research funding institutions and universities were little involved. ${ }^{15}$ In Europe, the German chemical industry had good research and development capability, while in the United States GeneralElectric, International Business Machines (IBM) Manhattan Project. New York, Harper.

${ }^{8}$ Bush, V.1945. President Roosevelt's Letter, The White House, Washington, D.C., November 17, 1944, Science: the Endless Frontier. Washington: National Science Foundation, p. 3.

${ }^{9}$ Ibid.

${ }^{10} I d$., pp. 3-4.

${ }^{11} I d$., p. 4.

${ }^{12}$ Zachary G. Endeless frontier: Vannevar Bush, engineer of the American century. New York: The Free Press; 1997. p. 91.

${ }^{13}$ Kevles D. The national science foundation and the debate over postwar research policy, 1942-1945: a political interpretation of science - the endless frontier. Isis. 1977;68(1):4.

${ }^{14}$ Cruz C. Ciência: a Fronteira sem Fim, uma apresentação. Revista Brasileira Inovação. 2014;13(2):243.

${ }^{15}$ Ibid. and Western Electric Company (WEC)-followed by the American Telephone and Telegraph (AT \& T) with his Bell Labs-devoted them to elementary and applied research. ${ }^{16}$ Universities in the United States presented relevant results with several Nobel Prizes winners. ${ }^{17}$ However, this universe of award-winners was far inferior to that of European universities, and Vannevar Bush recognized this reality by emphasizing that after the war the United States could not rely on European discoveries, "We can no longer count on Europe, destroyed, as a source of fundamental ideas." 18 After obtaining President Roosevelt's letter of recommendation, Vannevar Bush formed four committees which comprised recognized leaders in academic and industrial research in the United States, and conceived, debated, and legitimized a proposal that was handed over to the government. With the report Science: The Endless Frontiers "Bush produced a political document, a textual weapon for the political battles that took place from 1945 to 1950 on the form, objectives, and definitions of federal policy for post-war scientific research and development". ${ }^{19}$

On July 25, 1945 he prepared the document Science: The Endless Frontiers, which was delivered to President Henry S. Truman (18841972), because President Roosevelt had died in April of that year. The Science: the Endless Frontiers report consists of six parts, which are: Part One-Introduction, includes Scientific Progress is Essential; Part Two - The War on Disease; Part Thre -Science and the Public Welfare; Part Four-Renewal of Our Scientific Talent; Part Five-A Problem of Scientific Reconversion; Part Six-The Means to the End. ${ }^{20}$ As a note in "Scientific progress is essential", the report begins by giving special emphasis to science and scientific knowledge that allowed the discovery of penicillin and its use which prevented suffering and countless loss of lives. It also shows that the discovery of radar spared British cities from the Luftwaffe bombing and led the Allies to a military victory over Germany. In 1939, scientific advances provided millions of jobs in the new industries that had not existed at the end of the Great War-radio, air conditioning, cellulose and synthetic fibres and plastics. Agriculture also benefited from the scientific progress through more resistant plants, new farming practices and insect control. ${ }^{21}$ The advances of Science when put into practice would lead to more jobs, better salaries and quality of life. ${ }^{22}$ However, to achieve these goals and ensure a high level of commitment and a leading position worldwide - the flow of new scientific knowledge should be continuous and

${ }^{16}$ We give as an example the physicist Irving Langmuir (1881-1957) of the (G. E.) laboratories, who in 1932 received the Nobel Prize for Surface Chemistry and the physicist Clinton Joseph Davisson (1881-1958) from Western Electric who five years later would also win the Nobel Prize in Physics.

${ }^{17}$ By Albert Abraham Michelson (1852-1931) Physics (1907), Robert Andrew Millikan (1868-1953) Physics (1923), Arthur Holey Compton (1892-1962) Physics (1927), Thomas Hunt Morgan (1866-1945) in Physiology and Medicine (1933), by George Hoyt Whipple (1878-1976), William Parry Murphy (1892-1987), Georges Richards Minot (1885-1950) in Physiology and Medicine (1934), Harold Clayton Urey (1893-1981) at Chemistry (1934), Carol David Anderson in Physics (1936) and Ernest Orland Lawrence in Physics (1939).

${ }^{18}$ Cit. Cruz C. Ciência: a Fronteira sem Fim, uma apresentação. Revista Brasileira Inovação, Campinas (SP), 2014;13(2);244.

${ }^{19} \mathrm{Kevels} \mathrm{D}$. The national science foundation and the debate over postwar research policy, 1942-1945: a political interpretation of science-the endless frontier. Isis. 1977. 68(1):4.

${ }^{20}$ Bush V. Scientific Progress Is Essential. Science: The endless frontiers. Washington DC: National Science Foundation. 1945. p. V-VI.

${ }^{21}$ Bush V. Scientific Progress Is Essential. Science: The endless frontiers. Washington D.C: National Science Foundation. 1945. 10 p.

${ }^{22} \mathrm{Ibid}$. 
substantial. ${ }^{23}$ The welfare, health and safety of the country are of great concern to the government, but scientific progress must be considered of vital interest. ${ }^{24}$ The report shows that there was no organization responsible for developing, coordinating and implementing a national scientific policy. ${ }^{25}$ It reinforces that Science has been removed from the centre of attention of the government when it is the basis for the development of any Nation. The government must actively support areas of science in which the public interest is important-research on military affairs, agriculture, industry, housing, public health and medical research. ${ }^{26}$ Except for war research conducted by the Office of Scientific Research and Development (OSRD) support was minor and discontinuous. ${ }^{27}$ Colleges, universities and research institutes with public and private financial support and free research would allow for the creation and flow of new scientific and technological knowledge. ${ }^{28}$ In the section dedicated to the study of the "War against disease" 29 the report emphasizes the issues related to Military Medicine and the absence of an agency to support medical studies after the $\mathrm{War}^{30}$ It demonstrates that progress in the treatment of some diseases cardiovascular, renal, cancer and refractory diseases - will only be achieved through discoveries not connected to these same diseases. Medicine and the underlying sciences -Chemistry, Physics, Anatomy, Biochemistry, Physiology, Pulmonology, Bacteriology, Pathology and Parasitology - should be developed. It also suggests to the Medical Advisory Committee (MAC) that it should initiate an elementary research program in medical schools and universities. ${ }^{31}$ It notes that the proposed program be managed by a Division of Medical Research of the National Research Foundation (FNM) and that a second organization, the National Foundation for Medical Research (NFMR), should be created. Both proposals were accepted and resulted in a department within the National Science Foundation (NSF) which sponsored essential medical science, the Division of Biological and Medical Sciences (DBMS) and an independent organization the National Institute of Health (NIH) ${ }^{32}$ The National Science Foundation aided elementary research with the aim of improving knowledge in the fields of biology and medicine. Although the US Public Health Service and the National Science Foundation were the primary sources of financial resources for medical research, we should also list the Programs of the Veterans Administration, the Military Services, Medical Research and the Atomic Energy Commission (AEC). ${ }^{33}$

In the materialization of the field "Science and public welfare", ${ }^{34}$ it begins by observing the urgent need for the government to focus on scientific development and the creation of a governmental body responsible for formulating the national scientific policy that the different committees believed not to exist. ${ }^{35}$ This was carried out by

${ }^{23} I d$. p. 11

${ }^{24} \mathrm{Ibid}$.

${ }^{25} I d$. p. 12.

${ }^{26}$ Ibid.

${ }^{27}$ Ibid.

${ }^{28} \mathrm{Ibid}$.

${ }^{29} I d$., pp. 13-15.

${ }^{30} I d$., pp. 13

${ }^{31} I d$., pp. $14-15$

${ }^{32}$ The government supported medical and health science programs, which shows Congress's interest in the progress of medical research. The health institutes also increased the number of research grants aimed at acquiring scientific knowledge to care for and cure diseases.

${ }^{33} I d$., pp. 15-16.

${ }^{34} I d$., pp. 17-22.

35Id., p.17. the National Science Foundation in regard to basic research and by the President's Science Advisory Committee on matters in which the chief executive was responsible for direct action and by the Federal Council on Science and Technology in the coordination and planning of branches of government involved in the investigation. ${ }^{36}$ In Congress there were three very specific permanent committees directly related with Science and Technology, the Committee on Atomic Energy (CAE), the Senate Committee on Aeronautical and Space Sciences (SCASS) and the House Committee on Science and Astronautics (HCSA).

The Report highlights the importance of elementary research as the "pacemaker of technological progress". ${ }^{37}$ "A nation which depends upon others for its new development basic scientific knowledge will be slow in its industrial progress and weak in its competitive position in world trade" 38 Universities and public and private institutes are presented as key centres for the creation of scientific knowledge and highly trained researchers. ${ }^{39}$ It was through elementary research in biology, biochemistry and other sciences that it was possible to treat some diseases. National defence, economic and industrial growth was also dependent on basic research. ${ }^{40}$ It reminds the government of the need to strengthen scientific research through the creation of a Science Advisory Board (SAB) with the task of guiding government on budget policy and government agencies involved in scientific research. Regarding industrial research, he explained that the "most effective way in which the Government can strengthen industrial research is to support basic research and develop scientific talent"41

The section "Renewal of scientific talent" 42 highlights the importance of teaching - education and science - through the implementation of a national science scholarship program and the creation of a national science reserve to which the government, in moments of scientific emergency, could resort. ${ }^{43}$ It gives priority to scientific areas such as Engineering, Medicine, Geology, Chemistry, Geography, Metallurgy, Physics and Dentistry. The report refers the generation in uniform - all recruits and officers - warning the government of the need to develop efforts for its applicability in specialized areas, where they could develop the capabilities acquired during the war. ${ }^{44}$ The Naval Postgraduate School had programs of advanced education for the qualification of people and directly supported, through subsidies, the advanced training of the military in the universities. Secondary education is particularly important, especially in science, and there should be an improvement in teaching at this level with qualified teachers and properly equipped laboratories. They would start in study groups in physical sciences at the Massachusetts Institute of Technology aiming to update contents in Physics, Mathematics, Chemistry and Biology. ${ }^{45}$

\footnotetext{
${ }^{36} \mathrm{Ibid}$.

${ }^{37} I d .$, p. $18-19$.

${ }^{38} \mathrm{Ibid}$.

${ }^{39} \mathrm{Ibid}$.

${ }^{40} \mathrm{Ibid}$. Technology.

${ }^{42} I d$., pp. 23-27

${ }^{43} I d .$, p. 25.

${ }^{44}$ Ibid.

${ }^{45} I d$., p. 24.
}

${ }^{41}$ This council should be made up of scientists without connection to the government. The coordination of scientific activity, as well as policies and budgets were of the responsibility of the Federal Council on Science and 
In "Effects of the mobilization of science for war", ${ }^{46}$ the note on the knowledge of scientists acquired in laboratories, factories, universities, institutes and at the front which made possible the development of weapons, other material and from projects controlled by the Scientific Research Office has particular relevance. ${ }^{47}$ From a strategic point of view, this knowledge contributed to the efforts of the soldiers at the front and helped to shorten and win the war. ${ }^{48}$ It recommends that knowledge acquired in the military industry should be directed towards civilian industry. The scientific dissemination of the latest developments in the war industry provided a solid foundation for national security, while bearing in mind the concern that potential enemies could have access to this information. ${ }^{49}$ Teams of scientists worked on scientific issues but had little information about what other teams had accomplished or were doing. The Office of Scientific Research and Development was forced to comply with this practice during the War. The report stresses that the strategic ability of the United States to confront and win future wars depended on Scientific and technological advances. ${ }^{50}$ In regard to "The Means to the end" we note the "Foundations for military scientific investigation" 51 in which the report recalls that the Office of Scientific Research and Development had its successful program in the investigation of war-weapons and devices-and medical military. It warns of the need for long-range military and civilian research during the war and in peacetime..$^{52}$ It would complement the existing one on the improvement of weapons and could be carried out in military establishments. For this purpose, it is considered fundamental to create a Division of National Defense at the National Research Foundation. The military services were pleased with the military research developed at universities and institutes under the sponsorship of the Office of Scientific Research and Development and entered into new contracts to launch other research projects. The central laboratories - Laboratory of Applied Physics at Johns Hopkins University (Baltimore Maryland), the Radiation Laboratory at MIT and the NASA Jet Propulsion Laboratory of the California Institute of Technology (Caltech)-originally associated with contracts with the Office of Scientific Research and Development, also developed research supported by military funds, but operated and under civilian management. ${ }^{53}$ The aim of the army and the navy was to prepare personnel and invent weapons which would lead to victory in combat. The military establishment was not specialized in all fields of scientific research which would provide the Nation with a consistent and effective defence to successfully win a full scale war. It is curious that between the publication of this report and the promulgation of legislation by the National Science Foundation in 1950, the Navy Department through the Office of Naval Research granted support to a diversity of scientific areas. Later, government directives adopted a similar model by the Department of the Army through Ordnance Research and Air Force from the Air Force Office of Scientific Research. Engineer Vannevar Bush's proposal that military research should be conducted in time of peace and war by civilians independent of military establishments allowed a large number of senior scientists from the Department of Defense and outside institutions to be able to work on and perfect military problems..$^{54}$

\section{Conclusion}

In conclusion, the Report recommends to the government, the creation of a National Research Foundation to support research in the different sciences - Engineering, Physics, Chemistry and Medicine and training of personnel in research, national defence and international scientific cooperation and an organization for the American research system into five major pillars: Scientific research (civil and military); Industry (civil and military); Education (colleges, universities and institutes); Laboratories (private and state); Government to plan and finance projects. Engineer Vannevar Bush, defender of government financing education and research, points out in several parts of the program that "freedom of research must be preserved", using the metaphor "Frontier" used in President Roosevelt's letter "frontiers of thought" and then in the title of the report to justify that science should be aided by government and be free from limits. It attaches strategic importance to elementary research for having provided the United States with numerous high-impact achievements before and during the War. It recommends the financial contribution of the government through a system of scholarships for industry as a means of training new scientific talents. As for the renewal of these same talents, it suggests a system of scholarships for undergraduate and graduate students to be awarded by merit in association with the improvement of science teaching. The Report had a huge impact in the United States and other countries around the world. In Brazil (São Paulo) it was the basis of the researchers' proposal to the 1947 Constituent Assembly that resulted in the creation of Fapest. In the United States it was important in colleges, universities and research institutes. As Agar observes, after the war the American government understood the power that could come from Science. The Army, the Navy and the Air Force have created the conditions that have allowed them to stimulate basic research with universities and institutes and to develop the training of their personnel. The report formulated the events from the time and created the objective conditions for the development of governments' support for Science all over the World including Portugal. The idea in the report that the United States should have a coherent policy for science and technology seems to have been well accepted by American society. Vannevar Bush and his associates influenced the events that followed - the Korean War (1950-1953), the Cold War (1945-1991), the missile, the satellite, the Soviet technological challenge and space research, energy growth including large-scale programs and the use of nuclear energy for peaceful purposes. They contributed to the significant progress of science and education that would be central to the growth of the United States after the war and to NATO's science and technology policy.

\section{Acknowledgements}

None.

\section{Conflict of interest}

Author declares that there is no conflict of interest.

\footnotetext{
${ }^{46} I d$., pp. 28-30.

${ }^{47} I d$., p. 28.

${ }^{48} \mathrm{Ibid}$.

${ }^{49} I d .29$.

${ }^{50} I d .$, p. 30.

${ }^{51} I d .$, pp. 33-34

${ }^{52} I d$., p. 33.

${ }^{53} \mathrm{Ibid}$.

${ }^{54}$ Ibid.
} 